\title{
Bibliographic and Research Aids in Soviet Studies: A Summary Report of the Greyston Conference
}

\begin{abstract}
A conference was held in November 1966 to assess future library-related needs in the field of Soviet studies. Six working papers were prepared, on questions of bibliography, new technology, indexing, acquisitions, preservation, and a proposed center. Sponsors of the conference were the Joint Committee on Slavic Studies and COCOSEERS (Coordinating Committee for Slavic and East European Library Resources). Reprinted as it appears in the American Council of Learned Societies' Newsletter (March 1966) the article summarizes the conference papers and recommendations.
\end{abstract}

$\mathrm{T}$ O APPRAISE the state of bibliographic control in an interdisciplinary field requires broad perspective. Under today's conditions of rapid change in information technology it is a matter of some urgency to provide the background for informed decisions.

There are, for example, those who advocate a new approach for Soviet studies through the establishment of a documentation center designed to facilitate services to libraries and to specialists. With or without a center, others say, there is much to be done with both traditional and new techniques once current needs are properly analyzed.

In an attempt to review and assess some of these questions a Conference on Bibliographic and Research Aids in Soviet Studies was held November 19 to 22, 1966, at Greyston Conference Center, New York, New York. The conference was cosponsored by the Joint Committee on Slavic Studies (of the American Council of Learned Societies and the Social Science Research Coun-

Miss Buist is Slavic Bibliographer, Columbia University Libraries. cil) and the Coordinating Committee for Slavic and East European Library Resources (COCOSEERS ). ${ }^{1}$ Columbia University acted as host at the conference center in Riverdale.

The conference brought together approximately forty persons-academic and government specialists, librarians, and foundation officials-to review the current state of library and bibliographic development in Soviet studies, to assess major deficiencies and needs, and to recommend new solutions and programs for the future.

The program was built around six working papers: Zdenek David, Princeton University, "Bibliographic and Reference Aids"; Theodore C. Hines, Columbia University, "New Trends in Library Science and Technology"; Vaclav Mostecky, Harvard law school, "Abstracting, Translating and Indexing”; Philip E. Leinbach and Charles Gredler, Harvard University, "Acquisitions and Acces-

${ }^{1}$ Those who served on the Planning Committee for the conference were Cyril E. Black (chairman of COCOSEERS, 1965-66); Eleanor Buist; Alexander Dallin; John M. Thompson (chairman of the Joint Committee on Slavic Studies, 1965-66); and Gordon B. Turner, vice-president, American Council of Learned Societies. 
sions"; Melville J. Ruggles, Council on Library Resources, "Preservation and Reproduction"; and Thomas T. Hammond, University of Virginia, "Bibliographic, Documentation, and Information Center." This author served as rapporteur and also reported briefly on two annual meetings of the International Federation of Library Associations and the Federation Internationale de Documentation, in September 1966.

In lieu of formal publication of the conference proceedings, some aspects of the papers-hopefully those of more general interest-are summarized in the following paragraphs.

\section{Bibliographic and Reference Aids}

Dr. David's historically based survey was keyed to an appendix-bibliography of some two hundred items. In keeping with the scope of the conference the emphasis was on general bibliography and on materials published in Russian in the Soviet Union and its historical antecedents, with the purpose of uncovering deficiencies in bibliographic coverage and suggesting new tools. Three types of recommendations were summarized for the conference.

First, there is need for the reprinting of various bibliographies and indexes, both the very scarce early volumes and recent ones not readily available. ${ }^{2}$

Second, Dr. David oftered suggestions for revisions ${ }^{3}$ and new aids. A union

${ }^{2}$ Publications singled out were the annual Bibliografiia sovetskoi bibliografii $(1939,1946-1956)$ and its predecessor Bibliografiia russkoi bibliografii (19131922, and 1929); the index to periodical articles, Letopis' zhurnal' nykh statei (1926-1956); the several indexes to publications of the Academy of Sciences from the mid-1920's to the mid-1950's; the Ezhegodnik dissertatsii (1936-1937) and the Bibliografiia dissertatsii (1941-1945); the Spisok knig vyshedshikh v Rossii (1884-1907); several general bibliographies for the nineteenth century, especially those by Storkh and Adelung, Smirdin, Krasheninnikov, Ol'khin, Glazunov, and Suvorin; and the separately published indexes to important journals and newspapers of the nineteenth and twentieth centuries. (A clearinghouse for reprint information was proposed at the conference. More precise information as to the titles recommended by Dr. David will be on record when it is established.)

${ }^{3}$ The works suggested for revision are Serial Publications of the Soviet Union, 1939-1957, compiled by list of periodicals is needed, along the lines of Serial Publications of the Soviet Union 1939-1957, compiled by R. Smits. (Representatives of the Library of Congress informed the conference of the current state of this special card catalog. There are eighteen thousand entries for periodicals of the Soviet Union from 1917 to 1966, and approximately fourteen thousand cross-references. A subject index is in preparation.) Publication would provide more complete and accurate information on American library holdings than could be given in the third edition of the Union List of Serials. There is similarly a need for a new union list of Russian newspapers and the updating of the Ruggles and Mostecky survey and of the Morley guide.

Among the new bibliographies recommended are one for publications on internal developments in the USSR since 1917; specialized bibliographies in subject fields of the humanities and social sciences; and a bibliography of ephemera.

For Russian and Soviet government publications an updating of those sections of Gregory's List of the Serial Publications of Foreign Governments is needed. Descriptions of outstanding Russian collections in American libraries are desirable, as well as catalogs where these would not be largely duplicative of ones already published.

In the area of Russian emigré publications a comprehensive retrospective bibliography of books was recommended by Dr. David together with indexes to the major journals and an updating of the guide to serials.

Rudolf Smits (Washington: Library of Congress, 1958); Melville J. Ruggles and Vaclav Mostecky, Russian and East European Publications in the Libraries of the United States (New York: Columbia University Press, 1960); Charles Morley, Guide to Research in Russian History (Syracuse, N.Y.: Syracuse University Press, 1950); List of the Serial Publications of Foreign Governments, ed. by W. Gregory, (New York: Wilson, 1932), p. 658 ff.; Institute for the Study of the USSR, Ukazatel periodicheskikh izdanii emigratsii iz Rossii $i$ SSSR za 1919-1952 gg. (Munich: 1953). 
A bibliography of indexes to major Russian periodicals of the nineteenth and early twentieth centuries should be compiled, and indexes to the contents of periodicals are needed for the following: yearly or quarterly author indexes to Knizhnaia letopis' for the years when none are available or the existing ones cover less than quarterly periods; quarterly author indexes to Letopis' zhurnal 'nykh statei (when lacking); and indexes to major Russian periodicals of the nineteenth and early twentieth centuries.

Third, Dr. David pointed to projects requiring cooperation with the Soviet Union. Reproduction of one of the Lenin library's chief catalogs, the union catalog of Russian books to 1917, would be valuable even in microfilm inasmuch as the major Soviet work in progress for the nineteenth century, in sixty volumes or more, is not expected to be completed for many years. Needed, too, is the reproduction of the card catalog of Soviet dissertations deposited in the Lenin library, particularly for the period 19451955 , as well as some bibliographies of the Academy of Sciences' publications for the years 1938 to 1943 which exist only in typewritten form.

The Academy of Sciences' Fundamental Library of the Social Sciences issues a series of bulletins which are bibliographies of new Soviet literature in several subject fields, and include journal and newspaper article references as well as monographs. Dr. David recommended increased availability of these bulletins.

\section{New Trends and Techniques in}

\section{Library SCIENCE aNd TeChNOLOGY}

Dr. Hines noted that the research on new ways of organizing information in the aftermath of Sputnik, at times has resulted in financial support for new agencies and methods at the expense of existing ones. Even in the more affluent area of science two major libraries have had severe problems in maintaining their collections. He also pointed out that university scientists would not be better off, bibliographically speaking, than university social scientists if it were not for the overflow of services generated outside the university library by government and industry.

Nevertheless, if funds were forthcoming, the specialists in Soviet studies could have the same array of services that are now available to most scientists. These are, for example, "table of contents services; current awareness service through permuted title indexes of various kinds; computer-based published indexes using human-generated indexing terms; computer tapes created as part of the process of generating the published indexes which contain far more indexing terms than the published indexes and which may be searched by computer; citation indexes; selective dissemination of information to individuals; and, of course, a wealth of new abstracting services, micropublication, and mass distribution of report literature, and a plenitude of photocopying services usually not available to the Soviet studies scholar." Such services are provided in science by specialized agencies, large and small, which exist to organize the literature of a particular field for abstracting, indexing, publishing, and searching.

Trends in information research, briefly characterized, indicate that permutation indexing and citation indexing produce tools in which "brute force replaces subtlety"; that computer searching of centrally produced tapes with human choice of index entries is gradually being reduced in cost so that it is now competitive with manual searching; that computer typesetting is a significant development which should bring publishing and information retrieval closer together in the long run; that research in classification techniques is active, as well as in vocabulary control through thesauri or subject heading lists; and that there 
is continuing effort to promote indexing at the source of publication of journal articles.

To prevent "computer intoxication" Dr. Hines warned that "the success of console or on-line systems for computational work does not mean that they are ready for informational work." The new technology will not solve problems that require intellectual solution first. Much confusion has resulted from some reported research which mistakes a small, experimental universe for a large, real universe. These and other factors make it difficult for the scholar in another field to know what to ask when seeking help from information scientists.

The scholar, on the other hand, may be guilty of various other sins, such as expecting that a classification system devised for his own files is suitable for computer application to the whole literature of his discipline.

Dr. Hines' general recommendations to the Soviet area scholars and librarians were, first, to join in doing what could be done economically in their own institutions and, second, to seek jointly for financial aid in those matters where better service could be provided by today's technology. At the same time the scholar should help support adequate national and subject bibliography on a broad national and international level, through government and the societies. In recent years the needs of the day have been mobilized by the scientist to bring about the necessary tools for his work, and this could be achieved by the social scientist. Proven new techniques, and better ones through research, "are yours for the asking and the paying," he concluded.

\section{Abstracting, Translating, And INDEXING}

Mr. Mostecky defined seven audience groups ranging from the general public at the base of a pyramid extending to the scholars and other specialist writers and researchers in journalism and government, each group having different requirements. The multiplicity of serially issued services, exemplified by a list of seventy-eight titles in the Appendix to his paper, is a reflection of the diversity of needs. "What appears at first glance as a hopeless duplication of effort," he wrote, "in reality is a series of multicolored spotlights illuminating the stage with some degree of overlapping and a good deal of darkness left. To create a single monolithic stream of light that would suppress the shades of color would be unfortunate. However, the possibilities of better coordination of the spotlights and the restriction of the dark area must be further examined."

Among the major services in the United States are The Current Digest of the Soviet Press, the F.B.I.S. (Foreign Broadcast Information Service), the Joint Publications Research Service, the series published by the International Arts and Sciences Press, and the Monthly Index of Russian Accessions. Of these, the first four are major translating services and the last a bibliographic index with translated titles. The Current Digest of the Soviet Press also provides a unique weekly index to the contents of Pravda and Izvestiia, as well as a quarterly index (not cumulative) to the selection of articles which it translates from those newspapers and other periodicals.

After reviewing the characteristics and coverage of the major services, as well as translations published abroad and the Soviet services in English, Mr. Mostecky evaluated the group from the point of view of duplication and scattering, availability, adequacy, possible over-extension of the translating program as a whole, the question of area versus subject specialization and, finally, the problem of indexing.

His conclusions and recommendations were that, first, an up-to-date listing of 
all available services is needed. Second, the fast news services issued by governmental or quasi-governmental agencies or by news media operate for definite internal purposes with some recognized and inevitable overlapping. They are available to the research community. The translating activity in social science periodicals is, however, in dire need of coordination. A step in this direction would be to have the academic research community establish a working relationship with the Joint Publications Research Service.

Third, an expansion of The Current Digest of the Soviet Press to include abstracts is strongly recommended. Fourth, there is an overriding need for a consolidated and cumulative index to Soviet materials. This could start with indexing translated materials. Such an index would be a focal point for a documentation center which would maintain close contact with the Library of Congress, federal government agencies, and academic research centers.

As to method and equipment, fully automated systems are not sufficiently perfected for indexing, but a "judicious application of electronic techniques" combined with conventional indexing input is the most promising.

Rather than the subject heading arrangement of the present Monthly Index of Russian Accessions and indexes of The Current Digest of the Soviet Press, a topical arrangement is suggested. "It might, for example, follow the Library of Congress or, better yet, the Universal Decimal Classification with its hierarchical coding, possibly best suited for machine application." In aiming for compatibility with other area indexes (China, for example) it should be noted that "topical, hierarchical coding also provides a quick solution to the problems of synonyms, special or unique terminology, and foreign terms, as it is based on underlying logical concepts rather than mere words. It is the only system which can be used internationally without any major rearrangements."

\section{Acquisitions AND ACCEssions}

Mr. Gredler and Mr. Leinbach noted the marked improvement in the over-all picture that has taken place in the period of less than a decade since the RugglesMostecky report, and the increasing cooperation of Soviet libraries.

Methods endorsed by the authors include the checking by full-time librarians of all the selection tools for current publications. Faculty responsibility should be limited to checking secondhand lists and to providing advice on general selection policies. Prompt ordering is essential. The utility of exchanges is beyond question and should be expanded.

The categories of current material still difficult to procure are provincial serials (local newspapers and journals of the provincial universities and pedagogical institutes), dissertations, and printed dissertation abstracts. The authors recommended that a representative go to the Soviet Union to explore these problems. Retrospective materials most difficult to obtain are pamphlets, journals, and irregular series of the 1920 's and 1930's. Cooperative filming would help relieve this situation.

Messrs. Gredler and Leinbach strongly endorsed the principle of division of "depth" collecting responsibility among libraries, citing as an example Harvard's early decision to specialize in certain periods and subjects in Russian history. Present-day circumstances which should encourage this include the improved possibilities for sharing resources, and better physical access to other libraries.

Urging support for the National Program on Acquisitions and Cataloging, established by the Higher Education Act of 1965 (Title II, Part C, Section 231), the authors stated that "everyone concerned with Soviet research materials 
should back the Library of Congress in every possible way. Groups such as the Association of Research Libraries, the Joint Committee on Slavic Studies, and the American Association for the Advancement of Slavic Studies should expend time and money to ensure that this program is brought to fruition as soon as possible." They also recommended that serials be included in the program which is limited in its initial stages to monographs.

The authors called attention to the Center for Research Libraries, formerly the Midwest Inter Library Center, in Chicago. As an established repository for less-used materials it is seeking to expand its programs for the filming of foreign archives and of foreign newspapers, and for acquiring foreign dissertations. The acquisition of all current science serials of the Academy of Sciences of the USSR is being expanded to include the social sciences and will probably extend to the humanities. The Center is in need of additional library memberships and financial support.

A proposed selection guide was endorsed, to be based on the best consensus obtainable from the scholarly community. The proposal was made at a conference on Area Studies and the Library, held in $1965 .^{4}$

In summary, the authors stated: "We have urged support of two agencies with programs of national services already under way-the Library of Congress and the Center for Research Libraries. We have recommended the expanded use of exchanges and the use of a representative in the Soviet Union to explore further exchanges. We have proposed the cooperative filming of early Soviet serials and pamphlets. We have reinforced proposals for a rating of current Soviet publications and a new survey of American library holdings along the lines of

\footnotetext{
4 Eleanor Buist, "Area Programs for the Soviet Union and East Europe: Some Current Concerns of the Libraries," The Library Quarterly, XXXV (October 1965), 310-25.
}

the Ruggles-Mostecky report. We have urged that a division of collecting responsibilities be made."

\section{Preservation and Reproduction of Soviet Publications}

The paper presented by Mr. Ruggles pointed first to the grim fact that changes in papermaking methods, not limited to Russia but occurring elsewhere during the nineteenth century, will result in vast numbers of unusable books by the end of the twentieth century. While some librarians have long been concerned, most publishers continue to be indifferent.

Efforts of the Council on Library Resources, among others, to initiate appropriate action have resulted in three major developments in the United States. A permanent/durable paper developed by William J. Barrow's research is now marketed at a price close to that of other quality paper. Second, for books already in bad condition a chemical solution for treatment of deteriorating paper has been devised, also through research conducted by Mr. Barrow, but the problem of applying it to books at a reasonable cost has not been solved. Additional research is underway at the University of Chicago, by Richard D. Smith. Third, a comprehensive program has been worked out by a Committee on the Preservation of Research Library Materials of the Association of Research Libraries. The report prepared by Gordon Williams appeared in two issues of the Library Journal (January 1 and 15, 1966). The Library of Congress has assumed responsibility for a national program and will conduct a pilot project for identification of priorities.

In the matter of books of Soviet manufacture, tests on those issued between 1954 and 1957, conducted by Mr. Barrow, were reported by Mr. Ruggles in the February 1960 issue of the Slavic Review. In recent tests a smaller sampling of books published between 1964 
and 1966 showed no improvement in paper quality.

One of the paradoxes is that Soviet research on matters of preservation and restoration is highly advanced but so far has not improved the quality of the paper being used. The better state of preservation of books in Soviet libraries as compared with their condition in U.S. libraries may be related to factors of climate and temperature. The advantage, however, may delay the Soviets' adoption of permanent/durable paper, in which case our problem in handling their publications will continue indefinitely.

As a distant ray of hope Mr. Ruggles suggested "that if new materials can be fabricated for any unusual requirement in space technology, and if some of them, like teflon, can become so cheap to manufacture that they can be found as part of common utensils in ten-cent stores, it would seem that if some people put their mind and will to it we could have a truly permanent and durable substance on which the knowledge of our civilization could be recorded."

Even if obsolescence were to be overcome for all current publications it would still be necessary to take steps to preserve what has been printed. The method of copying is common but has many drawbacks. Among them are copyright laws. If the Soviet Union were to adhere to the international copyright convention, matters would change overnight. There are also the hazards of human and machine failure in the process of copying. Microcopying presents other hazards, not the least of which is the condition of spots on microfilm, now the subject of intensive research with no solution found as yet. "Hard copy" reprinting is a very young industry with special problems. Librarians should make their criticisms known to the industry, in order to improve the product. Mr. Ruggles recommended, in conclusion, "A special effort to study the voluminous technical literature published in the Soviet Union about the making of paper, the production of books, and the preservation of books and documents." Since we are also guilty of issuing impermanent publications, we should be able to discuss matters freely with Soviet librarians, publishers, and other responsible authorities, and should bring up the subject at international meetings and elsewhere.

For preservation programs underway in the United States priorities will have to be established. There are sound reasons why Slavicists as a group should press for priorities for Russian materials in this program. Those reasons include "the importance of the USSR in the world community and the specially delicate quality of the paper in Russian publications." In addition, the advice and assistance of Slavicists will be needed in any comprehensive plan.

In matters of reprinting, insistence on permanent/durable paper will benefit libraries. Libraries should also make their copies available to the publishers and request free copies in exchange.

A clearinghouse for desiderata would benefit all, and a special one for Slavic materials is needed to collate the requests of many institutions. The unified reprints list compiled by Marilyn May and Avis Bohlen, which appeared as two supplements to the Cahiers $d u$ monde russe et soviétique, "have been an important service to scholarship and one might hope that they will be continued."

\section{Proposal for a Bibliographic, DOCUMENTATION, AND INFORMATION Center}

In the working paper for Session VI, Professor Hammond stressed the need for a center with a permanent staff of

\footnotetext{
- Cyrillic Publications Concerning the Social Sciences and Humanities; Current List of Reproductions (2 vols.; "Cahiers du monde russe et soviétique," Supplements I and II; Paris: Mouton, 1964-65).
} 
full-time employees. In order to promote discussion he then listed many possible functions, stating that "the fact that I have listed a particular function does not mean that it is necessarily favored by me or by COCOSEERS. Some of the functions listed are problems of great urgency, while others might be looked upon as luxuries."

On behalf of the smaller institutions he strongly endorsed the need for a centralized book selection and purchasing system. This would have a panel of scholars under contract to select and rate current acquisitions on a scale of priorities and supply the books together with Library of Congress cards to client libraries choosing such a service. The commercial aspect of the system should help to finance other operations of the center. The data on all new books brought under a form of computer control would generate a significant body of bibliographic information for other purposes.

Other proposals related to a center include the appointment of a purchasing agent in Moscow for American libraries; the investigation of a "Farmington Plan" division of responsibility among American libraries for collecting in subject fields, and improved liaison with book dealers to provide advice on the needs of American scholars and libraries. A particular need is for control of so-called "fugitive" materials. Examples are "papers delivered at scholarly meetings (many of which are never published); mimeographed reports produced at Russian research centers, Radio Free Europe research reports and reports of Radio Liberty; embassy press releases; press releases of TASS, Novosti, and BBC; reports issued by various emigré organizations." Along these lines "the Center could act as a depository for all papers read at meetings of the American Association for the Advancement of Slavic Studies and the Association of Teachers of Slavic and East European Languages, as well as at the regional Slavic conferences."

Other functions suggested for the center would be to keep in touch with the new program on acquisitions and cataloging at the Library of Congress; to survey needs for bibliographies, indexes, and guides; to study the application of new machine technology; to advise commercial firms on needed reprints; to assist in distributing unclassified government reports not duplicated in sufficient quantities; to collect reports of American scholars returning from research trips; and to issue a newsletter for libraries and scholars.

Professor Hammond reported that proposals for other bibliographic projects and centers in related fields point to considerable overlapping of interest among specialists on Russia, China, Eastern Europe, and the field of history. "It would seem essential, therefore, that our Soviet Center, at the very least, keep in close touch with these other groups so as to coordinate activities, share knowledge and experience, and avoid duplication of efforts."

Considerations pointing to the advisability of locating the center in Washington, D.C. were described as follows: "First of all, it should be close to the Library of Congress because of the dominant position which LC holds in acquisitions, cataloging, indexing, and so on. Furthermore, the large staff of specialists at LC would be available for consultation and assistance. Some of the suggested functions of the Center point to Washington as the best location. Let me mention again: obtaining and reproducing unpublished U.S. government materials, maintaining contact with Congress, liaison with other government agencies, keeping up with developments in machine technology and advising U.S. officials during negotiations with Soviet representatives." In addition to the greater likelihood of financial support from government, Professor Hammond point- 
ed out in conclusion: "If it is decided to place the Center under the supervision of the Association of Research Libraries, this also points to Washington. . . . In addition, the Council on Library Resources is located in Washington, and the American Library Association has an office there."

\section{Summary of NeEDS}

The conference had been called to serve as a forum for expressions of opinion rather than as a group which would be expected to take formal action by resolution or vote. At the final session the participants discussed a provisional list which members of the Planning Committee considered to be representative of the numerous suggestions advanced, recognizing that priorities would have to be established. The list of needs, intended to serve as the basis for written commentary to the sponsors, is reproduced below with minor revisions:

Indexing, abstracting, and translating needs include: (1) closer coordination of present translating and abstracting services in the social science fields; (2) exploration of quick "current awareness" lists; (3) gradual development of a current, comprehensive index to social science and humanities materials in Soviet studies.

In future planning for bibliographic and reference aids there is need for: (4) consultation and contracting for the preparation of new reference tools; (5) control of ephemera by bibliographic listing, with the possibility of a depository.

Measures to promote preservation and reproduction should include: (6) encouragement of high priority for Soviet materials in preservation programs, local and national; (7) central planning through a clearinghouse for reprinting, with emphasis on deteriorating items; (8) promotion of a union list of microform reproductions and coordination of future efforts.

Recommendations for acquisitions and other areas of technical services include: (9) exploration of a division of labor in collecting; (10) provision of guides to selection; (11) the sending of a representative to the Soviet Union to explore exchange of publications with provincial universities and pedagogical institutes; (12) continuing support of the National Program on Acquisitions and Cataloging; (13) consultation on aids to retrospective cataloging.

General recommendations for implementing the above include: (14) the exploration of cooperation with the Soviet Union on specific projects; (15) obtaining the services of a consultant to survey the application of new technical developments to Soviet studies' bibliographic problems; (16) the establishment of a center as a clearinghouse and coordinating and consultative agency.

There was widespread support among the participants for the establishment of a center, even though opinions varied as to its scope and definition. The meeting of COCOSEERS held in New York City on November 23,1966 , unanimously endorsed the general proposal for founding a center, recommending primarily advisory, rather than depository, functions.

In the words of one commentator, some proposals made at the conference appear to emerge from a "bibliographer's dream." Nevertheless, the concern for a bolder plan should result at the very least in the improvement of some services to an important field. 